\title{
Polymorphism of lipid exchange genes in some populations of South and East Siberia
}

\author{
L.E. Tabikhanova ${ }^{1,3}$ @, L.P. Osipova ${ }^{1,3}$, E.N. Voronina ${ }^{2,3}$, A.O. Bragin ${ }^{3}$, M.L. Filipenko ${ }^{2,3}$ \\ ${ }^{1}$ Institute of Cytology and Genetics, SB RAS, Novosibirsk, Russia \\ 2 Institute of Chemical Biology and Fundamental Medicine, SB RAS, Novosibirsk, Russia \\ ${ }^{3}$ Novosibirsk State University, Novosibirsk, Russia \\ 凶e-mail: tabikhan@bionet.nsc.ru
}

Lipid metabolism disorders underlie the pathogenesis of a number of diseases. Indigenous peoples of Siberia have a specific genetically determined type of metabolism supporting such lipid blood parameters that favor increased consumption (in comparison with Caucasians) of animal products. At the same time, indigenous Siberian ethnic groups are less susceptible to metabolic diseases. The objective of the presented study was to investigate the allele frequencies of lipid metabolism genes in indigenous populations of Siberia to identify the ethnic features of allele frequency distribution for polymorphic variants in genes CETP (G1264A, rs5882), LPL (C1791G, rs328) and FTO (C83401A, rs8050136) in the samples taken from Buryats, Teleuts and Russians of Eastern Siberia, and to compare them with data on world populations. Samples of the Eastern $(N=132)$ and Western $(N=278)$ Buryats, Teleuts $(N=120)$, Russians $(N=122)$ and persons of mixed Buryat-Russian origin $(N=56)$ were genotyped by real-time PCR using competitive TaqMan-probes. The obtained results have for the first time demonstrated that the CETP and FTO allele frequencies in the Buryat samples are intermediate between European and East Asian populations. Significantly lower incidence of the obesity-assossiated 83401A allele of the FTO gene has been shown in Buryats, compared with Russians, which is consistent with lower susceptibility of the indigenous ethnic groups to metabolic disorders. There have been no population differences in the distribution of $L P L$ gene polymorphic variants associated with dyslipidemia, which means they probably do not contribute to the ethnic characteristics of the lipid profile. The intermediate frequencies of the CETP $1264 G$ and FTO $83401 \mathrm{~A}$ alleles found in the metis group demonstrate that the metabolic disorders associated with these variants can be rather expected in the descendants of mixed marriages than among Buryats. It has also been demonstrated that Teleuts differ by FTO $83401 \mathrm{~A}$ allele frequency from some of the European groups and have the lowest detected frequency of the allele CETP $1264 G$ associated with the favorable lipid blood parameters.

Key words: Buryats; Teleuts; Russians of Eastern Siberia; mixed origin; real-time PCR; lipid metabolism; genetic polymorphism; CETP (rs5882); LPL (rs328); FTO (rs8050136).

For citation: Tabikhanova L.E., Osipova L.P., Voronina E.N., Bragin A.O., Filipenko M.L. Polymorphism of lipid exchange genes in some populations of South and East Siberia. Vavilovskii Zhurnal Genetiki i Selektsii =Vavilov Journal of Genetics and Breeding. 2019;23(8):1011-1019. DOI 10.18699/VJ19.578

\section{Полиморфизм генов липидного обмена в некоторых популяциях Южной и Восточной Сибири}

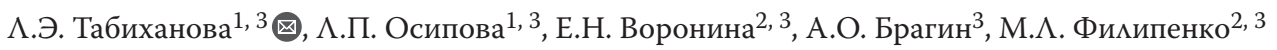 \\ 1 Федеральный исследовательский центр Институт цитологии и генетики Сибирского отделения Российской академии наук, Новосибирск, Россия \\ ${ }^{2}$ Институт химической биологии и фундаментальной медицины Сибирского отделения Российской академии наук, Новосибирск, Россия \\ ${ }^{3}$ Новосибирский национальный исследовательский государственный университет, Новосибирск, Россия \\ 冈e-mail: tabikhan@bionet.nsc.ru
}

Нарушения липидного обмена лежат в основе патогенеза ряда заболеваний. Коренные народы Сибири отличаются особым генетически обусловленным типом метаболизма, который поддерживает благоприятные липидные показатели крови при повышенном, по сравнению с европеоидами, вкладе в рацион продуктов животного происхождения. При этом коренные сибирские этносы меньше подвержены заболеваниям метаболического спектра. Цель настоящего исследования - изучение частот аллелей генов липидного обмена в коренных популяциях Сибири. Была поставлена задача на примере бурят, телеутов и русских Восточной Сибири выявить этнические особенности в распределении частот полиморфных вариантов генов CETP (G1264A, rs5882), LPL (C1791G, rs328) и FTO (C83401A, rs8050136) и сравнить с данными по мировым популяциям. Выборки восточных $(N=132)$ и западных $(N=278)$ бурят, телеутов $(N=120)$, русских $(N=122)$ и потомков смешанных браков бурят с русскими $(N=56)$ генотипированы с помощью ПЦР в режиме реального времени с использованием конкурирующих TaqMan-зондов. В настоящей работе впервые показано, что по частотам полиморфных вариантов генов CETP и FTO изученные выборки бурят находятся в промежуточном положении между европеоидными группами и популяциями Восточной Азии. Показана статистически значимо меньшая встречаемость у бурят, по сравнению 


\begin{abstract}
с русскими, аллеля 83401A гена FTO, ассоциированного с ожирением, что согласуется с меньшей подверженностью этого коренного сибирского этноса метаболическим нарушениям. Не выявлено популяционных различий в распределении полиморфного варианта LPL 1791G, связанного с дислипидемией, который, вероятно, не вносит заметного вклада в этнические особенности липидного профиля. Промежуточное значение частот аллелей CETP 1264 и и FTO 83401A в группе потомков смешанных браков бурят с русскими позволяет предположить больший риск ассоциированных с этими вариантами метаболических нарушений у лиц смешанного происхождения, чем среди бурят. У телеутов продемонстрирована пониженная частота FTO 83401A по сравнению с некоторыми европеоидными группами и выявлена наименьшая частота CETP 1264G, ассоциированного с благоприятными липидными показателями крови.

Ключевые слова: буряты; телеуты; русские Восточной Сибири; метисы; ПЦР в режиме реального времени; липидный обмен; генетический полиморфизм; CETP (rs5882); LPL (rs328); FTO (rs8050136).
\end{abstract}

\section{Introduction}

For centuries indigenous peoples of Siberia have been adapting to severe climatic and geographical conditions and predominantly protein-lipid diet, and are now characterized by a distinct type of metabolism with increased protein-lipid and minimized carbohydrate exchange (Panin, 1978). It was shown earlier that, if compared to the migrant population, representatives of Siberian ethnic groups, who preserved their traditional way of life, developed a favorable blood lipid profile characterized by decreased total cholesterol, triglycerides, low- and very low-density lipoproteins (LDL, VLDL), and increased high-density lipoproteins (HDL) preventing cardiovascular and other metabolism-associated diseases (Oteva et al., 1993; Sevostyanova, 2013; Darenskaya, 2014; Polyakov et al., 2015; Tsygankova et al., 2017). As the ongoing urbanization impacts the indigenous population, their living and economic conditions change, and the so-called 'civilization diseases' related to metabolic disorders increasingly strike the Siberian peoples (Ovsyannikova et al., 2007; Lyudinina et al., 2014).

Investigation of gene polymorphism in the metabolic profile of indigenous Siberian populations is critical for understanding the molecular-genetic foundations of adaptive potential they developed by adapting to specific climatic and geographical conditions and via certain nutritional habits, and for identifying genetic reserves of ethnic groups in a rapidly changing world (Hsieh et al., 2017; Hallmark et al., 2018). The goal of the present paper is to study the frequencies of the polymorphic variants of lipid exchange genes in Siberian populations, the functional significance being established based on data on world populations.

A CETP gene encodes a cholesteryl ester carrier (transfer protein) responsible for cholesterol transport from antiatherogenic HDL to atherogenic LDL (Koch et al., 2014). The data on a number of world populations show that carriers of the $G$ allele of the CETP polymorphic locus (G1264A, rs5882) reduce transfer protein activity and therefore increase HDL (Thompson et al., 2008) as well as decreased triglycerides compared to $A A$ homozygotes (Hosseini-Esfahani et al., 2019). In a number of studies, inverse associations of the $1264 \mathrm{G}$ allele increasing a risk of atherosclerosis have been found (Thompson et al., 2008; Cyrus et al., 2016). A twin study of European population showed that $G G$ homozygotes have lower body mass index, fat mass, and subcutaneous fat thickness, while $A A$ homozygotes demonstrated a faster weight gain under overnutrition (Teran-Garcia et al., 2008).
Studies in Caucasians, Americans of African origin, and Chinese revealed the $G G$ genotype could also be associated with longevity, reduced risk of the Alzheimer's disease, vascular dementia, and grey matter anomalies in posterior brain in healthy elderly people (Sanders et al., 2010; Yu et al., 2012; Chen et al., 2014; Salminen et al., 2015).

A lipoprotein lipase (LPL) enzyme plays a major part in fat consumption by tissues, as it is responsible for plasma triglyceride hydrolysis to generate free fatty acids and glycerol, thus converting VLDL into LDL and fulfilling tissues' energy requirements (Koch et al., 2014). The polymorphic locus $C 1791 G$ (rs328) of the $L P L$ gene is of interest to the researchers, since, as it was shown in a number of world populations, this $G$ allele has been associated with favorable changes in lipid composition, i. e. decrease in triglycerides and increase in HDL in healthy subjects (Sagoo et al., 2008; Webster et al., 2009; Tang et al., 2010; Shatwan et al., 2016). The $C C$ genotype is shown to be associated with metabolic syndrome in Mexican women of European and African descent and the descendants of indigenous peoples (Cahua-Pablo et al., 2015). In addition, $1791 G$ is a protective allele against Alzheimer's disease (Ren L., Ren X., 2016).

An FTO gene (fat mass and obesity associated gene) encodes 2-oxoglutarate-dependent demethylase for nucleic acids involved in central control of energy homeostasis (Kudryavtseva et al., 2010). In a genome-wide association study (GWAS) it was demonstrated that FTO gene polymorphism was associated with a risk of obesity (Babenko et al., 2019). The studies of the FTO polymorphic locus (C83401A, rs8050136) in world populations of various origins showed that $A$ allele carriers had decreased $F T O$ gene expression and increased a risk of obesity (Park et al., 2013; Chen et al., 2018). The FTO $(83401 A)$ variant was shown to be associated with type-2 diabetes mellitus in the Russian and East Asian populations (Suplotova et al., 2014; Yang et al., 2017).

We were unable to find any data on the CETP (G1264A, rs5882), LPL (C1791G, rs328), and FTO (C83401A, rs8050136) allele and genotype frequencies in indigenous Siberian peoples in the literature. In this respect we saw the objectives of our study as to investigate the incidence of these polymorphic variants in Buryats, one of the largest peoples in Eastern Siberia (over $460 \mathrm{~K} \mathrm{ppl}$, according to the 2010 census), Teleuts, a small indigenous people in Southern Siberia (about $2.5 \mathrm{~K} \mathrm{ppl}$ ), and Russians from Eastern Siberia; to compare the results to the data on world populations available in the 
literature; to match the results obtained with the data on prevalence of dyslipidemia among these ethnic groups. Of equal interest is the distribution of lipid exchange gene variants in descendants from mixed Russian-Buryat marriages, which is the reason they were included in the research as well.

\section{Materials and methods}

The genetic material for this study was collected by the employees of the Laboratory of Populational Ethnogenetics at the Institute of Cytology and Genetics, SB RAS (headed by L.P. Osipova, PhD) during the expeditions of 2003-2006. Blood samples were taken from volunteers, who were apparently healthy at the moment of the procedure after taking their informed consent and receiving the approval of local public health authorities and the Ethics Committee of the Institute of Cytology and Genetics, SB RAS. Before the blood samples were taken, every participant filled in a customized demographic questionnaire, where they specified the ethnic backgrounds of 3-4 generations of their ancestors. The data collected were used to form 5 population samples for the Southern and Eastern Siberia.

Persons of Buryat nationality having no ancestors with foreign ethnic backgrounds and living in Alkhanay and Orlovsky settlements of the Agin-Buryat Autonomous District (ABD) in Zabaykalsky Krai were included in the Eastern Buryat group $(N=132)$. Ethnic Buryats living in the settlements of the Ekhirit-Bulagatsky District of the Ust-Ordyn Buryat Autonomous District (UOBD) in the Irkutsk Region $(N=278)$ were included in the western sample. First- and second-generation descendants from mixed Russian-Buryat marriages were included in the metis sample $(N=56)$. The Teleut sample included the representatives of the indigenous population of Belovo District in the Kemerovo Region $(N=120)$. Longliving Russians from Eastern Siberia, whose ancestors lived in the settlements of Zabaykalsky Krai and the Irkutsk Region for several generations, were included in the fifth sample $(N=122)$.

DNA samples were recovered from venous blood leukocyte fractions using the Biosilica assay kits (Russia). Genotyping of single-nucleotide exchanges in the $C E T P(G 1264 A$, rs5882), $L P L(C 1791 G$, rs328), and FTO (C83401A, rs8050136) genes was performed via real-time PCR using competing TaqManprobes complementary to polymorphic DNA segments. Primer and probe structures were chosen based on the sequences available from the NCBI database (http://www.ncbi.nlm.nih. gov/) using UGENE (version 1.14, http://ugene.unipro.ru/) and Oligo Analyzer (version 1.0.3, https://eu.idtdna.com/ pages/tools/oligoanalyzer) software suites (Table 1).

PCR amplification volume was $25 \mu \mathrm{l}$, and PCR mixture included primers (300 nM), TaqMan-probes (100 nM), TrisHCl (65 mM, pH 8.9), $\left(\mathrm{NH}_{4}\right)_{2} \mathrm{SO}_{4}(16 \mathrm{mM}), \mathrm{MgCl}_{2}(2.5 \mathrm{mM})$, Tween-20 (0.05\%), dNTP (0.2 mM), DNA (0.5-10 ng), and Taq-DNA polymerase (0.5 U, hot-start, Biosan, IHBFM). PCR conditions were as follows: initial denaturation at $96{ }^{\circ} \mathrm{C}$ lasted $3 \mathrm{~min}$ and was followed by 46 cycles including denaturation at $96^{\circ} \mathrm{C}$ for $5 \mathrm{~s}$ and primer annealing with subsequent elongation at $61{ }^{\circ} \mathrm{C}$ for $30 \mathrm{~s}$ (each step was accompanied by a fluorescent signal recorded at the FAM and R6G fluorophore emission wavelength).

Population allele frequencies of polymorphic variants were determined based on the observed genotype frequencies. The match between the empirically observed genotype frequency distribution and the expected theoretical distribution in HardyWeinberg equilibrium was examined using $\chi^{2}$ Pearson test (the equilibrium holds at $p>0.05$ ). Significance of differences in allele frequencies between the studied samples was determined using $\chi^{2}$ test with Yates's correction for continuity; the results were considered statistically significant at $p<0.017$ (considering the multiple testing correction $0.017=0.05 / 3$ ).

\section{Results}

Genotype distribution for polymorphic loci of the CETP (G1264A, rs5882), LPL (C1791G, rs328), and FTO (C83401A, rs8050136) genes in samples of Buryats, their metis, Teleuts, and Russians from Eastern Siberia is presented in Table 2.

Genotype distribution matched the Hardy-Weinberg equilibrium for all polymorphic loci and samples. The CETP $1264 G, L P L 1791 G$, and FTO $83401 \mathrm{~A}$ allele frequencies in the studied samples, some additional ethnic groups described in the literature (The 1000 Genomes..., 2012), and population comparison ( $p$-value) are presented in Tables 3-5.

The CETP $1264 G$ allele associated with favorable lipid blood parameters is widely spread in Africa with the average frequency of $63.8 \%$ and the frequency in the Nigerian population reaching $69 \%$ (The 1000 Genomes..., 2012). It is slightly less common in South (the average of $45 \%$ ) and East Asian populations (the average of $43.7 \%$ ), as well as Central and South America (the average of $40.1 \%$ ). European populations are characterized by decreasing frequency of this protective allele against atherosclerosis with the average frequency of $33.1 \%$.

Table 1. Structures of the primers and probes used for genotyping of single-nucleotide exchanges in the CETP, LPL, and FTO genes

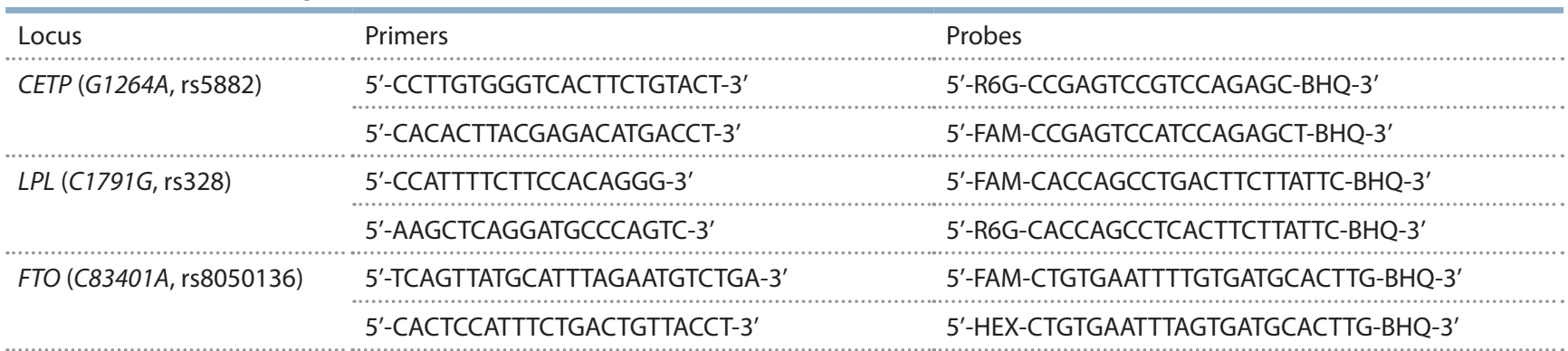


Table 2. Genotype distribution for CETP, LPL, and FTO in samples of Buryat, their metis, Teleuts, and Russians from Eastern Siberia

\begin{tabular}{|c|c|c|c|c|c|c|c|}
\hline Population & & & $\begin{array}{l}\text { Eastern } \\
\text { Buryats }\end{array}$ & $\begin{array}{l}\text { Western } \\
\text { Buryats }\end{array}$ & Metis & Teleuts & $\begin{array}{l}\text { Russians from } \\
\text { Eastern Siberia }\end{array}$ \\
\hline \multirow{5}{*}{$\begin{array}{l}\text { CETP (G1264A, } \\
\text { rs5882) }\end{array}$} & \multirow{3}{*}{$\begin{array}{l}\text { Genotype } \\
\text { distribution, } \\
n(\%)\end{array}$} & $A A$ & $51(38.6)$ & $125(44.9)$ & $27(48.2)$ & $68(56.7)$ & $58(47.5)$ \\
\hline & & $A G$ & $63(47.7)$ & $120(43.2)$ & $22(39.3)$ & 39 (32.5) & $52(42.6)$ \\
\hline & & GG & $18(13.7)$ & 33 (11.9) & 7 (12.5) & $13(10.8)$ & $12(9.8)$ \\
\hline & $N, \mathrm{ppl}$ & & 132 & 278 & 56 & 120 & 122 \\
\hline & $p(\mathrm{H}-\mathrm{W})$ & & 0.835 & 0.611 & 0.457 & 0.052 & 0.945 \\
\hline \multirow{5}{*}{$\begin{array}{l}\text { LPL (C1791G, } \\
\text { rs328) }\end{array}$} & \multirow{3}{*}{$\begin{array}{l}\text { Genotype } \\
\text { distribution, } \\
n(\%)\end{array}$} & $C C$ & $114(86.4)$ & 227 (81.9) & $47(87.0)$ & $96(82.8)$ & $102(83.6)$ \\
\hline & & $C G$ & $17(12.9)$ & $48(17.4)$ & $7(13.0)$ & $16(13.8)$ & 19 (15.6) \\
\hline & & GG & $1(0.7)$ & $2(0.7)$ & 0 & $4(3.4)$ & $1(0.8)$ \\
\hline & $N, \mathrm{ppl}$ & & 132 & 277 & 54 & 116 & 122 \\
\hline & $p(\mathrm{H}-\mathrm{W})$ & & 0.936 & 0.945 & 0.926 & 0.519 & 0.981 \\
\hline \multirow{5}{*}{$\begin{array}{l}\text { FTO (C83401A, } \\
\text { rs8050136) }\end{array}$} & \multirow{3}{*}{$\begin{array}{l}\text { Genotype } \\
\text { distribution, } \\
n(\%)\end{array}$} & $C C$ & $69(52.3)$ & $158(56.9)$ & $21(38.9)$ & $57(49.1)$ & $47(38.5)$ \\
\hline & & $C A$ & $56(42.4)$ & $106(38.1)$ & $25(46.3)$ & $46(39.7)$ & $56(45.9)$ \\
\hline & & $A A$ & $7(5.3)$ & $14(5.0)$ & $8(14.8)$ & $13(11.2)$ & 19 (15.6) \\
\hline & $N, \mathrm{ppl}$ & & 132 & 278 & 54 & 116 & 122 \\
\hline & $p(\mathrm{H}-\mathrm{W})$ & & 0.308 & 0.481 & 0.9 & 0.428 & 0.733 \\
\hline
\end{tabular}

Note: $N$ is the sample size; $n$ is the quantity; $p(H-W)$ is the probability of deviation from the Hardy-Weinberg equilibrium, metis are the descendants of mixed Russian-Buryat marriages.

Table 3. CETP 1264G allele frequency in some populations (ethnic groups) and population comparison ( $p$-value)

\begin{tabular}{|c|c|c|c|c|c|c|c|}
\hline \multirow[t]{2}{*}{ Population/ethnic group } & \multirow{2}{*}{$\begin{array}{l}N, \\
\text { ppl }\end{array}$} & \multirow{2}{*}{$\begin{array}{l}\text { CETP } 1264 G \\
\text { frequency, } \\
\%\end{array}$} & \multicolumn{5}{|c|}{ Population comparison ( $p$-value) } \\
\hline & & & $\begin{array}{l}\text { Eastern } \\
\text { Buryats }\end{array}$ & $\begin{array}{l}\text { Western } \\
\text { Buryats }\end{array}$ & Metis & Teleuts & $\begin{array}{l}\text { Russians from } \\
\text { Eastern Siberia }\end{array}$ \\
\hline Eastern Buryats* & 132 & 37.5 & & 0.296 & 0.378 & 0.017 & 0.155 \\
\hline Western Buryats* & 278 & 33.5 & 0.296 & & 0.859 & 0.089 & 0.559 \\
\hline Metis* & 56 & 32.1 & 0.378 & 0.860 & & 0.401 & 0.947 \\
\hline Teleuts* & 120 & 27.1 & 0.017 & 0.089 & 0.401 & & 0.385 \\
\hline Russians from Eastern Siberia* & 122 & 31.1 & 0.155 & 0.559 & 0.947 & 0.385 & \\
\hline Han Chinese, Beijing, China ${ }^{* *}$ & 103 & 47.6 & 0.035 & $p<0.001$ & 0.011 & $p<0.001$ & $p<0.001$ \\
\hline Southern Han Chinese, China ${ }^{* *}$ & 105 & 43.3 & 0.236 & 0.015 & 0.066 & $p<0.001$ & 0.009 \\
\hline Japanese, Tokyo, Japan** & 104 & 52.9 & 0.001 & $p<0.001$ & $p<0.001$ & $p<0.001$ & $p<0.001$ \\
\hline $\begin{array}{l}\text { Kinh (Viet) Ho Chi Minh City, } \\
\text { Vietnam }^{* *}\end{array}$ & 99 & 38.4 & 0.920 & 0.247 & 0.324 & 0.016 & 0.132 \\
\hline $\begin{array}{l}\text { Population of the state of Utah, } \\
\text { descendants of Northern and Western } \\
\text { European settlers }\end{array}$ & 99 & 35.9 & 0.798 & 0.600 & 0.581 & 0.061 & 0.335 \\
\hline Finns, Finland** & 99 & 35.4 & 0.714 & 0.691 & 0.643 & 0.077 & 0.393 \\
\hline English people and Scots ${ }^{* *}$ & 91 & 29.7 & 0.109 & 0.391 & 0.762 & 0.632 & 0.838 \\
\hline Iberians, Spain ${ }^{*}$ & 107 & 30.8 & 0.151 & 0.529 & 0.909 & 0.444 & 0.974 \\
\hline Toscani, Italy ${ }^{* *}$ & 107 & 33.6 & 0.430 & 0.953 & 0.881 & 0.160 & 0.638 \\
\hline
\end{tabular}

Note: Hereinafter: metis are the descendants of mixed Russian-Buryat marriages; ${ }^{*}$ the research data; ** the data from the literature (The $1000 \mathrm{Genomes...,2012);}$ $p<0.017$ are highlighted in bold if the differences have been considered statistically significant. 
Table 4. LPL $1791 \mathrm{G}$ allele frequency in some populations (ethnic groups) and population comparison ( $p$-value)

\begin{tabular}{|c|c|c|c|c|c|c|c|}
\hline \multirow[t]{2}{*}{ Population/ethnic group } & \multirow{2}{*}{$\begin{array}{l}N, \\
\text { ppl }\end{array}$} & \multirow{2}{*}{$\begin{array}{l}\text { LPL 1791G } \\
\text { frequency, } \\
\%\end{array}$} & \multicolumn{5}{|c|}{ Population comparison ( $p$-value) } \\
\hline & & & $\begin{array}{l}\text { Eastern } \\
\text { Buryats }\end{array}$ & $\begin{array}{l}\text { Western } \\
\text { Buryats }\end{array}$ & Metis & Teleuts & $\begin{array}{l}\text { Russians from } \\
\text { Eastern Siberia }\end{array}$ \\
\hline Eastern Buryats* & 132 & 7.2 & & 0.362 & 0.987 & 0.287 & 0.674 \\
\hline Western Buryats* & 277 & 9.4 & 0.362 & & 0.434 & 0.797 & 0.820 \\
\hline Metis* & 54 & 6.5 & 0.987 & 0.434 & & 0.351 & 0.647 \\
\hline Teleuts* & 116 & 10.3 & 0.287 & 0.797 & 0.351 & & 0.633 \\
\hline Russians from Eastern Siberia* & 122 & 8.6 & 0.674 & 0.820 & 0.647 & 0.633 & \\
\hline Han Chinese, Beijing, China** & 103 & 10.2 & 0.322 & 0.846 & 0.377 & 0.902 & 0.675 \\
\hline Southern Han Chinese, China ${ }^{* *}$ & 103 & 12.4 & 0.080 & 0.280 & 0.151 & 0.588 & 0.245 \\
\hline Japanese, Tokyo, Japan ${ }^{* *}$ & 104 & 11.1 & 0.189 & 0.572 & 0.263 & 0.907 & 0.463 \\
\hline $\begin{array}{l}\text { Kinh (Viet) Ho Chi Minh City, } \\
\text { Vietnam** }\end{array}$ & 99 & 13.1 & 0.050 & 0.184 & 0.113 & 0.451 & 0.170 \\
\hline $\begin{array}{l}\text { Population of the state of Utah, } \\
\text { descendants of Northern and Western } \\
\text { European settlers }\end{array}$ & 99 & 12.6 & 0.072 & 0.255 & 0.141 & 0.551 & 0.225 \\
\hline Finns, Finland ${ }^{* *}$ & 99 & 11.6 & 0.143 & 0.454 & 0.218 & 0.783 & 0.374 \\
\hline English people and Scots ${ }^{* *}$ & 91 & 11.5 & 0.163 & 0.497 & 0.234 & 0.817 & 0.407 \\
\hline Iberians, Spain** & 107 & 16.4 & 0.003 & 0.009 & 0.021 & 0.078 & 0.016 \\
\hline Toscani, Italy ${ }^{* *}$ & 107 & 12.6 & 0.066 & 0.239 & 0.136 & 0.539 & 0.214 \\
\hline
\end{tabular}

Table 5. FTO 83401A allele frequency in some populations (ethnic groups) and population comparison ( $p$-value)

\begin{tabular}{|c|c|c|c|c|c|c|c|}
\hline \multirow[t]{2}{*}{ Population/ethnic group } & \multirow{2}{*}{$\begin{array}{l}N, \\
\mathrm{ppl}\end{array}$} & \multirow{2}{*}{$\begin{array}{l}L P L 1791 G \\
\text { frequency, } \\
\%\end{array}$} & \multicolumn{5}{|c|}{ Population comparison ( $p$-value) } \\
\hline & & & $\begin{array}{l}\text { Eastern } \\
\text { Buryats }\end{array}$ & $\begin{array}{l}\text { Western } \\
\text { Buryats }\end{array}$ & Metis & Teleuts & $\begin{array}{l}\text { Russians from } \\
\text { Eastern Siberia }\end{array}$ \\
\hline Eastern Buryats* & 132 & 26.5 & & 0.511 & 0.038 & 0.314 & 0.005 \\
\hline Western Buryats* & 278 & 24.1 & 0.511 & & 0.004 & 0.055 & $p<0.001$ \\
\hline Metis* & 54 & 38.0 & 0.038 & 0.004 & & 0.249 & 0.976 \\
\hline Teleuts ${ }^{*}$ & 116 & 31.0 & 0.314 & 0.055 & 0.249 & & 0.105 \\
\hline Russians from Eastern Siberia* & 122 & 38.5 & 0.005 & $p<0.001$ & 0.976 & 0.105 & \\
\hline Han Chinese, Beijing, China** & 103 & 15.0 & 0.004 & 0.009 & $p<0.001$ & $p<0.001$ & $p<0.001$ \\
\hline Southern Han Chinese, China ${ }^{* *}$ & 105 & 13.8 & 0.001 & 0.003 & $p<0.001$ & $p<0.001$ & $p<0.001$ \\
\hline Japanese, Tokyo, Japan ${ }^{* *}$ & 104 & 17.3 & 0.023 & 0.056 & $p<0.001$ & 0.001 & $p<0.001$ \\
\hline $\begin{array}{l}\text { Kinh (Viet) Ho Chi Minh City, } \\
\text { Vietnam }\end{array}$ & 99 & 21.7 & 0.281 & 0.557 & 0.003 & 0.039 & $p<0.001$ \\
\hline $\begin{array}{l}\text { Population of the state of Utah, } \\
\text { descendants of Northern and Western } \\
\text { European settlers }\end{array}$ & 99 & 44.4 & $p<0.001$ & $p<0.001$ & 0.336 & 0.006 & 0.247 \\
\hline Finns, Finland ${ }^{* *}$ & 99 & 38.9 & 0.006 & $p<0.001$ & 0.975 & 0.106 & 0.990 \\
\hline English people and Scots** & 91 & 39.6 & 0.005 & $p<0.001$ & 0.884 & 0.085 & 0.897 \\
\hline Iberians, Spain ${ }^{* *}$ & 107 & 37.4 & 0.014 & $p<0.001$ & 0.987 & 0.185 & 0.884 \\
\hline Toscani, Italy ${ }^{* *}$ & 107 & 46.3 & $p<0.001$ & $p<0.001$ & 0.194 & 0.001 & 0.111 \\
\hline
\end{tabular}


The ethnic group of Russians from Eastern Siberia matches the other Caucasian populations described in the literature in the CETP $1264 G$ allele frequency (see Table 3). Our investigation showed that this allele frequency is higher in the Buryats than in the Russians, but statistically speaking it is still significantly lower than in a number of East Asian populations. The group of descendants of mixed Russian-Buryat marriages is intermediate between parent populations. The Teleuts, on the other hand, demonstrated the lowest CETP $1264 G$ frequency among not only the studied groups but among all the populations described earlier. The differences between the Teleuts, Eastern Buryats, and a number of East Asian populations are statistically significant.

Incidence of $L P L 1791 G$, a protective allele against a series of metabolic disorders, is relatively low in human populations (The 1000 Genomes..., 2012). For instance, it varies from 2.5 to $10 \%$ in African populations, from 2.4 to $8.7 \%$ in the indigenous American population, and from 5.2 to $10.8 \%$ in South Asian populations. The incidence of this allele in East Asian populations is $10.2-14 \%$ and in Europeans - 11.5-16.4 \%.

No significant differences in the incidence of the $L P L$ $1791 G$ allele were found between the studied samples of Buryats, Teleuts, and Russians (see Table 4). All the groups showed a slightly decreased value compared to the data on East Asian and European populations from the literature. However statistically significant differences were found only in the Buryats compared to the Caucasian population of Iberians characterized by the highest incidence of $1791 \mathrm{G}$.

The FTO $83401 A$ allele associated with high body mass index is widely spread in African populations at 38.1-46.8 \% and Caucasian populations - at 37.4-46.3\% (The 1000 Genomes..., 2012). It is less common in indigenous populations of Central and South America (21.9-34.6 \%) and South Asia (24.3-33.8\%). The incidence of $83401 \mathrm{~A}$ is even lower in East Asian, i. e. Chinese, Japanese, and Vietnamese, populations at $13.8-21.7 \%$.

The FTO $83401 \mathrm{~A}$ allele frequency in samples of Eastern and Western Buryats was statistically significantly lower than in samples of Russians from Eastern Siberia and Caucasian groups described in the literature (see Table 5). $83401 \mathrm{~A}$ allele was also less common in the Teleuts, than in the Russians. In addition, statistically significant differences between the Teleut sample and the Caucasian sample of the population of the state of Utah and the Toscani group from Italy were found. On the other hand, frequencies of the FTO $83401 \mathrm{~A}$ variant in Siberian samples significantly increased if compared to a number of East Asian groups. It was shown earlier for other gene frequencies that indigenous Siberian populations were intermediate between Caucasians and East Asians (Tabikhanova et al., 2018a, b).

\section{Discussion}

The present study is conducted within a topical line of research aiming to investigate specific features of population genetic structure in indigenous Siberian peoples in the context of medical biology and gene geography. Functionally significant CETP 1264G, LPL 1791G, and FTO $83401 A$ alleles have been studied for the first time in populations of Buryats, Teleuts, and Russians from Eastern Siberia, as well as the descendants from mixed Russian-Buryat marriages.
The discovered frequencies were shown to match the general geographical gradient regarding the distribution of CETP (G1264A, rs5882) and FTO (C83401A, rs8050136) polymorphic variants. The group of Russians from Eastern Siberia matches the other Caucasian populations. Siberian peoples are intermediate between Caucasian and East Asian populations, the only exception being the CETP $1264 G$ allele frequency in Teleuts having the lowest recorded frequency among all populations. The development of this population was probably affected by microevolutionary factors (such as genetic drift or passing through a bottleneck). Further research focused on extending the studied sample and covering other territorial groups of Teleuts is required to come to definitive conclusions.

$L P L(C 1791 G$, rs328) gene polymorphism does not show a pronounced frequency gradient on the world map, and no distribution regularities were found for the $L P L 1791 G$ allele in the samples studied.

It is worth noting that Buryats have higher ratio of cholesterol-rich animal foods in their diet compared to Russians, the prevalence of animal foods being a distinctive feature of their nutritional intake (Bairova et al., 2013). In addition, it has been shown that negative lipid profile changes (increase in triglycerides, total cholesterol, LDL, and VLDL) in Buryat women in their climacteric period were less noticeable than in the Russian ethnic group (Semenova et al., 2018). Cholesterol levels in patients with myocardial infarctions and diabetes mellitus type 2 are lower in the Buryat population than in patients from Caucasian populations (Bardymova et al., 2015). Adaptation to the hypercontinental climate of the Siberian region, livestock-based economy, and high-calorie diet with high protein and fat contents appears to have affected the frequencies of polymorphic variants of lipid exchange genes in this indigenous Siberian ethnic group.

Lower prevalence of lipid exchange disorders in Buryats matches the increased frequency of the CETP $1264 G$ allele associated with favorable lipid blood parameters and decreased incidence of obesity-associated FTO $83401 \mathrm{~A}$ in the population. We were unable to discover any differences in the $L P L 1791 G$ allele frequencies between the populations, and thus it may turn out to have no effect on a distinctive ethnic lipid profile. Further research into lipid exchange genes in the populations studied will make it possible to better understand the nature of ethnic differences.

Intermediate frequencies of polymorphic variants $C E T P$ $1264 G$ and FTO $83401 \mathrm{~A}$ in the metis group may indicate a higher risk of the associated metabolic disorders in descendants of mixed marriages. At the same time, the lowest incidence of $L P L 1791 G$ observed in the metis group is possibly due to the small sample size.

We were unable to find any data on distinctive features of lipid spectrum in Teleuts in the literature, however studies in Shorians, another small indigenous people in the Kemerovo Region, showed the trend of lower prevalence of dyslipidemias compared to migrant Caucasian populations, to be peculiar for Siberian ethnic groups (Tsygankova et al., 2017). At the same time, recent decades saw an increase in cardiovascular diseases in the representatives of a Teleut ethnic group living under environmentally unfriendly conditions in the urbanized areas of Kuzbass (intermountain basin) (Ovsyannikova et 
al., 2007). A decreased frequency of obesity-associated FTO $83401 \mathrm{~A}$ allele in Teleuts and Buryats has been demonstrated in the present paper, however the genetic differences of this indigenous Siberian ethnic group from Caucasians are not too significant, as it has been shown earlier for other genes (Tabikhanova et al., 2018a, b). A low frequency of the CETP $1264 G$ allele associated with the favorable lipid blood parameters in the population may indicate an increased risk of dyslipidemies in a specific territorial group of Teleuts.

\section{Conclusions}

Ethnic distinctions in the frequency distribution of the polymorphic variants of the CETP (G1264A, rs5882), LPL $(C 1791 G$, rs328), and FTO (C83401A, rs8050136) genes in Siberian populations of Buryats, Teleuts, Russians, and descendants of mixed Russian-Buryat marriages have been studied in the present paper for the first time.

The Buryat samples were shown to be intermediate between Caucasian groups and East Asian populations in CETP $1264 G$ and FTO $83401 A$ frequencies. Compared to the Russians, the Buryats showed a statistically significantly lower incidence of the FTO $83401 \mathrm{~A}$ allele associated with obesity. This agrees with the lower susceptibility of Buryats to metabolic disorders compared to the Caucasian population described in the literature. Intermediate frequencies of CETP $1264 \mathrm{G}$ and FTO $83401 \mathrm{~A}$ alleles in the metis group may indicate a higher risk of the associated metabolic disorders in the descendants of mixed marriages compared to the Buryats.

A decreased FTO $83401 A$ was demonstrated in Teleuts, however the genetic differences of this indigenous Siberian ethnic group from Caucasians are not too significant; Teleuts also showed the lowest CETP $1264 G$ frequency among all the populations studied. The results of the present study may imply an increased risk of dyslipidemia in this specific territorial group of Teleuts.

No differences were found in distribution of the polymorphic variant $L P L 1791 G$ associated with dyslipidemia, and thus it may turn out to have no effect on a distinctive lipid profile of these Siberian peoples.

\section{References}

Babenko V.N., Babenko R.O., Gamieldien G., Markel A.L. FTO haplotyping underlines high obesity risk for European populations. BMC Med. Genomics. 2019;12(2):46. DOI 10.1186/ s12920-019-0491-x.

Bairova T.A., Dolgikh V.V., Kolesnikova L.I., Pervushina O.A. Nutriciogenetics and risk factors of cardiovascular disease: associated research in Eastern Siberia populations. Byulleten' VSNTs SO RAMN = Bulletin ESSC SB RAMS. 2013;4(92):87-92. (in Russian)

Bardymova T.P., Protasov K.V., Donirova O.S., Tsyretorova S.S., Berezina M.V. Ethnic features of myocardial infarction and diabetes mellitus in patients of the Buryat population. Abstracts from the VII Russian Diabetology Congress "Diabetes mellitus in the 21st century: time to unite efforts", 2015 Feb. 24-27. Moscow, 2015;121. (in Russian)

Cahua-Pablo J.A., Cruz M., Méndez-Palacios A., AntúnezOrtiz D.L., Vences-Velázquez A., Alarcón-Romero L.C.,
Parra E.J., Tello-Flores V.A., Leyva-Vázquez M.A., Valladares-Salgado A., Pérez-Macedonio C.P., Flores-Alfaro E. Polymorphisms in the $L P L$ and CETP genes and haplotype in the ESR1 gene are associated with metabolic syndrome in women from Southwestern Mexico. Int. J. Mol. Sci. 2015;16:21539-21554. DOI 10.3390/ijms160921539.

Chen B., Li Z., Chen J., Ji J., Shen J., Xu Y., Zhao Y., Liu D., Shen Y., Zhang W., Shen J., Wang Y., Shi Y. Association of fat mass and obesity-associated and retinitis pigmentosa guanosine triphosphatase (GTPase) regulator-interacting protein-1 like polymorphisms with body mass index in Chinese women. Endocr. J. 2018;65(7):783-791. DOI 10.1507/ endocrj.EJ17-0554.

Chen J.J., Li Y.M., Zou W.Y., Fu J.L. Relationships between CETP genetic polymorphisms and Alzheimer's disease risk: a meta-analysis. DNA Cell Biol. 2014;33(11):807-815. DOI 10.1089/dna.2013.2265.

Cyrus C., Vatte C., Al-Nafie A., Chathoth S., Al-Ali R., AlShehri A., Akhtar M.S., Almansori M., Al-Muhanna F., Keating B., Al-Ali A. The impact of common polymorphisms in $C E T P$ and $A B C A 1$ genes with the risk of coronary artery disease in Saudi Arabians. Hum. Genomics. 2016;10(8). DOI 10.1186/s40246-016-0065-3.

Darenskaya M.A. Features of metabolic reactions in indigenous and migrant populations of Northern Russia and Siberia. Byulleten' VSNTs SO RAMN = Bulletin ESSC SB RAMS. 2014;2(96):97-103. (in Russian)

Hallmark B., Karafet T.M., Hsieh P.H., Osipova L.P., Watkins J.C., Hammer M.F. Genomic evidence of local adaptation to climate and diet in indigenous Siberians. Mol. Biol. Evol. 2018;36(2):315-327. DOI 10.1093/molbev/msy211.

Hosseini-Esfahani F., Esfandiar Z., Mirmiran P., Daneshpour M.S., Ghanbarian A., Azizi F. The interaction of cholesteryl ester transfer protein gene variations and diet on changes in serum lipid profiles. Eur. J. Clin. Nutr. 2019; 73:1291-1298. DOI 10.1038/s41430-019-0397-x.

Hsieh P.H., Hallmark B., Watkins J.C., Karafet T.M., Osipova L.P., Gutenkunst R.N., Hammer M.F. Exome sequencing provides evidence of polygenic adaptation to a fat-rich animal diet in indigenous Siberian populations. Mol. Biol. Evol. 2017;34(11):2913-2926. DOI 10.1093/molbev/msx226.

Koch N.V., Lifschitz G.I., Voronina E.N. Approaches to the lipid metabolism genes polymorphism analysis in screening for atherosclerosis risk factors. Rossiyskiy Kardiologicheskiy Zhurnal = Russian Journal of Cardiology. 2014;10(114):5357. DOI 10.15829/1560-4071-2014-10-53-57. (in Russian)

Kudryavtseva E.A., Voronina E.N., Lifshits G.I., Krapivina N.A., Tsvetovskaya G.A., Filipenko M.L. No influence of polymorphic variants of genes INSIG2, FTO, GNB3 on the severity of obesity in patients with metabolic syndrome. Vestnik Novosibirskogo Gosudarstvennogo Universiteta. Seriya: Biologiya, klinicheskaya meditsina $=$ Bulleten of Novosibirsk State University. Ser.: Biology, clinical medicine. 2010;8(3):32-39. (in Russian)

Lyudinina A.Yu., Potolitsyna N.N., Solonin Yu.G., Osadchuk L.V., Gutorova N.V., Petrova P.G., Troev I.P., Ostobunaev V.V., Boyko E.R. Lipid profile in men of Komi and Yakut ethnic groups with overweight and obesity. 
Ekologiya Cheloveka = Human Ecology. 2014;1:13-19. (in Russian)

Oteva E.A., Maslennikov A.V., Nikolaeva A.A., Osipova L.P., Evseeva O.L., Sherental' I.S., Filimonova T.A., Pikovskaja N.V. Features of serum lipid composition in northern Selkups. Terapevticheskiy Arkhiv $=$ Therapeutic Archive. 1993;65(1):21-24. (in Russian)

Ovsyannikova O.V., Podkhomutnikov V.M., Kolbasko A.V., Luzina F.A., Gus'kova E.V. Cardiovascular disease in rural Kuzbass aborigines - Teleut. Rossiyskiy Kardiologicheskiy Zhurnal = Russian Journal of Cardiology. 2007;12(6):59-62. (in Russian)

Panin L.E. Energy Aspects of Adaptation. Leningrad, 1978. (in Russian)

Park S.L., Cheng I., Pendergrass S.A., Kucharska-Newton A.M., Lim U., Ambite J.L., Caberto C.P., Monroe K.R., Schumacher F., Hindorff L.A., Oetjens M.T., Wilson S., Goodloe R.J., Love S.A., Henderson B.E., Kolonel L.N., Haiman C.A., Crawford D.C., North K.E., Heiss G., Ritchie M.D., Wilkens L.R., Le Marchand L. Association of the FTO obesity risk variant rs 8050136 with percentage of energy intake from fat in multiple racial/ethnic populations. Am. J. Epidemiol. 2013;178(5):780-790. DOI 10.1093/aje/kwt028.

Polyakov L.M., Rozumenko A.A., Osipova L.P., Kunitsyn V.G., Goltsova T.V. Serum lipid spectrum of indigenous and alien population of Yamalo-Nenets Autonomous Okrug. Sibirskiy Nauchnyy Meditsinskiy Zhurnal = The Siberian Scientific Medical Journal. 2015;35(6):66-69. (in Russian)

Ren L., Ren X. Meta-analyses of four polymorphisms of lipoprotein lipase associated with the risk of Alzheimer's disease. Neurosci. Lett. 2016;619:73-78. DOI 10.1016/ j.neulet.2016.03.021.

Sagoo G.S., Tatt I., Salanti G., Butterworth A.S., Sarwar N., Maarle M., Jukema J.W., Wiman B., Kastelein J.J., Bennet A.M., Faire U., Danesh J., Higgins J.P. Seven lipoprotein lipase gene polymorphisms, lipid fractions, and coronary disease: a huge association review and meta-analysis. Am. J. Epidemiol. 2008;168(11):1233-1246. DOI 10.1093/aje/ kwn235.

Salminen L.E., Schofield P.R., Pierce K.D., Luo X., Zhao Y., Laidlaw D.H., Cabeen R.P., Conturo T.E., Lane E.M., Heaps J.M., Bolzenius J.D., Baker L.M., Cooley S.A., Scott S., Cagle L.M., Paul R.H. Genetic markers of cholesterol transport and gray matter diffusion: a preliminary study of the CETP I405V polymorphism. J. Neural. Transm. 2015;122:1581-1592. DOI 10.1007/s00702-015-1434-0.

Sanders A.E., Wang C., Katz M., Derby C.A., Barzilai N., Ozelius L., Lipton R.B. Association of a functional polymorphism in the cholesteryl ester transfer protein (CETP) gene with memory decline and incidence of dementia. JAMA. 2010;303(2):150-158. DOI 10.1001/jama.2009.1988.

Semenova N.V., Madaeva I.M., Darenskaya M.A., Gavrilova O.A., Zhambalova R.M., Kolesnikova L.I. Lipid profile in menopausal women of two ethnic groups. Acta Biomedica Scientifica. 2018; 3(3):93-98. DOI 10.29413/ ABS.2018-3.3.14. (in Russian)

Sevostyanova Ye.V. Some features of human lipid and carbohydrate metabolism in the North. Byulleten' Sibirskoy
Meditsiny $=$ Bulletin of Siberian Medicine. 2013;12(1):93100. (in Russian)

Shatwan I.M., Minihane A.M., Williams C.M., Lovegrove J.A., Jackson K.G., Vimaleswaran K.S. Impact of lipoprotein lipase gene polymorphism, $S 447 X$, on postprandial triacylglycerol and glucose response to sequential meal ingestion. Int. J. Mol. Sci. 2016;17(3):397. DOI 10.3390/ijms17030397.

Suplotova L.A., Vakhromeeva K.A., Belchikova L.N., Nosikov V.V. Evalaution of association of genetic markers with type 2 diabetes in Russian population. Meditsinskaya Nauka i Obrazovanie Urala = Medical Science and Education of Ural. 2014;4:51-57. (in Russian)

Tabikhanova L.E., Osipova L.P., Churkina T.V., Voronina E.N., Filipenko M.L. Genetic polymorphism of CYP1A1 and CYP2D6 in populations of Buryats, Teleuts and Russians of Eastern Siberia. Vavilovskii Zhurnal Genetiki i Selektsii $=$ Vavilov Journal of Genetics and Breeding. 2018a;22(2):205-211. DOI 10.18699/VJ18.348. (in Russian)

Tabikhanova L.E., Osipova L.P., Churkina T.V., Voronina E.N., Filipenko M.L. Genetic polymorphism of F2, F5 and VKORC1 in populations of Buryats, Teleuts and Russians of Eastern Siberia. Molekulyarnaya Meditsina $=$ Molecular Medicine. 2018b;16(3):31-36. DOI 10.29296/249994902018-03-06. (in Russian)

Tang W., Apostol G., Schreiner P.J., Jacobs D.R., Boerwinkle E., Fornage M. Associations of lipoprotein lipase gene polymorphisms with longitudinal plasma lipid trends in young adults: The Coronary Artery Risk Development in Young Adults (CARDIA) Study. Circ. Cardiovasc. Genet. 2010;3(2):179-186. DOI 10.1161/ CIRCGENETICS.109.913426.

Teran-Garcia M., Despres J.P., Tremblay A., Bouchard C. Effects of cholesterol ester transfer protein (CETP) gene on adiposity in response to long-term overfeeding. Atherosclerosis. 2008;196:455-460.

The 1000 Genomes Project Consortium. An integrated map of genetic variation from 1,092 human genomes. Nature. 2012;491(7422):56-65. DOI 10.1038/nature11632.

Thompson A., Angelantonio E., Sarwar N., Erqou S., Saleheen D., Dullaart R., Keavney B., Ye Z., Danesh J. Association of cholesteryl ester transfer protein genotypes with CETP mass and activity, lipid levels, and coronary risk. JAMA. 2008;299(23):2777-2788. DOI 10.1001/jama.299.23.2777.

Tsygankova D.P., Mulerova T.A., Ogarkov M.Yu., Mikhalina E.V., Saarela E.Yu., Kazachek Ya.V., Kuzmina A.A., Barbarash O.L. Indicators of lipid metabolism in the inhabitants of Mountain Shoria: ethnic peculiarities and the impact of living conditions. Ateroskleroz i Dislipidemii $=$ The Journal of Atherosclerosis and Dyslipidemias. 2017;1(26):68-76. (in Russian)

Webster R.J., Warrington N.M., Weedon M.N., Hattersley A.T., McCaskie P.A., Beilby J.P., Palmer L.J., Frayling T.M. The association of common genetic variants in the APOA5, LPL and $G C K$ genes with longitudinal changes in metabolic and cardiovascular traits. Diabetologia. 2009;52:106-114. DOI 10.1007/s00125-008-1175-9. 
Yang Y., Liu B., Xia W., Yan J., Liu H.Y., Hu L., Liu S.M. FTO genotype and type 2 diabetes mellitus: spatial analysis and meta-analysis of 62 case-control studies from different regions. Genes. 2017;8(2):70. DOI $10.3390 /$ genes 8020070 .
Yu L., Shulman J.M., Chibnik L., Leurgans S., Schneider J.A., Jager P.L., Bennett D.A. The CETP $1405 \mathrm{~V}$ polymorphism is associated with an increased risk of Alzheimer's disease. Aging Cell. 2012;11(2):228-233. DOI 10.1111/j.14749726.2011.00777.x.

\section{ORCID ID}

L.E. Tabikhanova orcid.org/0000-0002-5547-8189

L.P. Osipova orcid.org/0000-0001-7602-1156

Acknowledgements. The work was supported by the Russian Scientific Foundation, project 19-15-00219: "The study of genetic determinants of multifactorial diseases in the indigenous peoples of Siberia". The authors thank T.M. Karafet, PhD, D.V. Lichman, PhD, N.A. Vavilova, N.A. Moletotova, S.S. Sangaev, PhD, and A.O. Likhacheva for their contribution to scientific expeditions and technical assistance.

Conflict of interest. The authors declare no conflict of interest.

Received May 29, 2019. Revised October 2, 2019. Accepted October 7, 2019. 